\title{
PENGARUH MEKANISME CORPORATE GOVERNANCE, UKURAN PERUSAHAAN DAN LEVERAGE TERHADAP MANAJEMEN LABA DAN KINERJA KEUANGAN
}

\author{
Raras Mahiswari \\ PT Bank Central Asia, Tbk (BCA) Yogyakarta \\ rarasmahiswari@yahoo.com \\ Paskah Ika Nugroho \\ Fakultas Ekonomika dan Bisnis, Universitas Kristen Satya Wacana \\ paskah@staff.uksw.edu
}

\begin{abstract}
The purpose of this study is to examine the influence of corporate governance mechanism, namely institutional ownership, managerial ownership,size of commissioner, presence of independent of commissioner, and size of audit committee, also firms size and leverage on earnings management. This research also examines the influence of earnings management on financial performance. The samples of 31 companies listed on Indonesian Stock Exchange (IDX), for a period of three years from 2007-2009 was selected. Data were analyzed by using multiple regression and simple regression. The results of this research showed that institutional ownership and leverage have a significant impact on earnings management. Managerial ownership, size of commissioner, presence of independent of commissioner, size of audit committee, also firms size have no significant relationships with earnings management. Next, earnings management has a significant impact on financial performance.
\end{abstract}

Keywords: Corporate Governance Mechanism, Earnings Management, Financial Performance

\section{PENDAHULUAN}

Manajemen yang dinilai prestasinya dalam menghasilkan laba,akan cenderung mengelola laba secara oportunis.Manajemen dapat meningkatkan laba sesuai dengan yang diinginkan dan menguntungkan pihak-pihak tertentu dengann melakukan manipulasi laporan keuangan.Hal ini dilakukan agar laba sesuai dengan tujuan yang diharapkan meskipun tidak sesuai dengan kondisi perusahaan yang sebenarnya. Oleh karena itu, manajemen perusahaan dapat menentukankebijakan 
penggunaaan metoda akuntansi dalam menyusun laporan keuangan untuk mencapai tujuan yang diinginkan perusahaan.

Dechow (dalam Siallagan dan Machfoedz 2006) menyatakan bahwa manajemen yang ingin menunjukkan kinerja yang baik dapat termotivasi untuk memodifikasi laporan keuangan agar menghasilkan laba seperti yang diinginkan oleh pemilik. Hal ini diprediksi dapat menimbulkan manipulasi laba yang sering diartikan sebagai manajemen laba. Banyak kasus manipulasi keuangan yang muncul karena perusahaan melakukan earning management, misalnya kasus manipulasi laporan keuangan yang dilakukan Enron, World Com dan sebagainya. Terjadinya manipulasi laporan keuangan tersebut karena lemahnya penerapan corporate governance. Ciri utama dari lemahnya corporate governance adalah adanya tindakan mementingkan diri sendiri di pihak para manajer perusahaan (Khomsiyah dan Rahayu 2004). Salah satu mekanisme yang dapat digunakan untuk mengatasi permasalahan keagenan tersebut adalah dengan menerapkan mekanisme tata kelola perusahaan yang baik (good corporate governance).

Untuk menghasilkan kinerja perusahaan yang baik pihak agent diharapkan menyusun laporan keuangan berdasarkan akuntansi berbasis akrual (accrualsaccounting). Financial Accounting Standard Board (FASB) (dalam Ujiyantho dan Pramuka 2007) menyebutkan bahwa akuntansi akrual mempunyai keunggulan bahwa informasi laba perusahaan dan pengukuran komponennya berdasarkan akuntansi akrual secara umum memberikan indikasi lebih baik tentang kinerja ekonomi perusahaan daripada informasi yang dihasilkan dari aspek penerimaan dan pengeluaran kas terkini. Akuntansi akrual juga memiliki kelemahan, yaitu akuntansi akrual merupakan aturan yang tidak sempurna dan mengaburkan laporan keuangan yang bertujuan memberikan informasi aliran kas dan kapabilitas perusahaan dalam menghasilkan kas. Kekaburan informasi ini diakibatkan akuntansi akrual yang rumit dan rentan akan manipulasi.

Zmijewski dan Hagerman (dalam Ujiyantho dan Pramuka2007) mengemukakan bahwa kelemahan akuntansi akrual ini menimbulkan peluang bagi manajer untuk mengimplementasikan strategi manajemen laba. Strategi ini dikategorikan menjadi pilihan kebijakan/metoda akuntansi dan discretionary accruals (kebijakan pengestimasian akuntansi). Boediono (2005) menjelaskan bahwa mekanisme good corporate governance memiliki kemampuan dalam kaitannya menghasilkan suatu laporan keuangan yang memiliki kandungan informasi laba. Laporan keuangan harusmenunjukkan informasi yang sebenarnya, agar tidak menyesatkan pihak pengguna laporan. Kebijakan dan keputusan yang diambil akan berpengaruh terhadap penilaian kinerja (Ujiyantho dan Pramuka 2007).

Selain penerapan corporate governance, faktor lain yang memengaruhi praktik manajemen laba yaitu ukuran perusahaan. Ukuran perusahaan yang kecil dianggap lebih banyak melakukan praktik manajemen laba daripada perusahaan besar. Perusahaan yang besar lebih diperhatikan oleh masyarakat sehingga mereka akan lebih berhati-hati dalam melakukan pelaporan keuangan, sehingga berdampak 
perusahaan tersebut melaporkan kondisinya lebih akurat (Nasution dan Setiawan 2007). Firth dan Smith (1992), dalam Saiful (2002) menjelaskan bahwa tingkat kewajiban yang tinggi menjadikan pihak manajemen perusahaan menjadi lebih sulit dalam membuat prediksi jalannya perusahaan ke depan. Semakin besar utang yang dimiliki perusahaan maka semakin ketat pengawasan yang dilakukan oleh kreditor, sehingga fleksibilitas manajemen untuk melakukan manajemen laba semakin berkurang.

Penelitian ini menggabungkan penelitian-penelitian sebelumnya yang meneliti pengaruh mekanisme corporate governace terhadap manajemen laba, yang dilakukan oleh Ujiyantho dan Pramuka (2007).Riset ini juga mengekstensi riset Rachmawati dan Triamoko (2007) tentang pengaruh manajemen laba terhadap kinerja keuangan dengan menambah variabel komite audit terhadap pengawasan terhadap manajemen. Tujuan penelitian ini adalah menganalisis pengaruh lima variabel mekanisme corporate governance (kepemilikan manajerial, kepemilikan institusional, proporsi dewan komisaris independen, ukuran dewan komisaris dan komite audit), ukuran perusahaan dan leverage terhadap manajemen laba serta konsekuensi manajemen laba terhadap kinerja keuangan.

\section{Teori Agensi}

Konsep teori agensi adalah hubungan atau kontrak antara prinsipal dan agen. Prinsipal memerkerjakan agen untuk melakukan tugas untuk kepentingan prinsipal, termasuk pendelegasian otorisasi pengambilan keputusan dari prinsipal kepada agen (Anthony dan Govindarajan 2005). Pada perusahaan yang modalnya terdiri atas saham, pemegang saham bertindak sebagai prinsipal dan Chief Executive Officer $(C E O)$ sebagai agen mereka. Pemegang saham memerkerjakanCEO untuk bertindak sesuai dengan kepentingan prinsipal. Konflik inilah yang kemudian dapat memicu kos agensi. Jensen dan Meckling (1976) mendefinisikan kos agensi dalam tiga jenis: kos monitoring (monitoring cost), kosbonding (bonding cost) dan kos residual (residual cost).

Eisenhardt (1989)dalam Ujiyantho dan Pramuka (2007) menyatakan bahwa teori agensi menggunakan tiga asumsi sifat manusia yaitu: (1) manusia pada umumnya mementingkan diri sendiri (self-interest), (2) manusia memiliki daya pikir terbatas mengenai persepsi masa mendatang (bounded rationality) dan (3) manusia selalu menghindari risiko (risk-averse). Dari asumsi sifat dasar manusia tersebut dapat dilihat bahwa konflik agensi yang sering terjadi antara manajer dengan pemegang saham dipicu adanya sifat dasar tersebut.

\section{Manajemen Laba}

Manajemen laba yaitu suatu kemampuan untuk memanipulasi pilihan-pilihan yang tersedia dan mengambil pilihan yang tepat untuk dapat mencapai tingkat laba yang diinginkan (Belkaoui 2004). Scott (2000) menyatakan bahwa terdapat beberapa pola dalam manajemen laba, yaitu: taking a bath, income minimization, income 
maximization danincome smoothing. Scott (2000) juga mengemukakan beberapa motivasi terjadinya manajemen laba, yaitu: bonus purposes, the debt covenant hypothesis, political motivations, taxation motivations, pergantian CEO dan Initital Public Offering (IPO).

\section{Mekanisme Corporate Governance}

Komite Nasional Kebijakan Corporate Governance (KNKCG) mendefinisi corporate governance adalah suatu proses dan struktur yang digunakan oleh perusahaan guna memberikan nilai tambah pada perusahaan secara berkesinambungan dalam jangka panjang bagi pemegang saham, dengan tetap memperhatikan kepentingan stakeholder lainnya, berlandaskan peraturan perundangan dan norma yang berlaku. Dalam KNKG terdapat aspek-aspek dalam rangka penyelenggaraan corporate governance yang baik, yaitu perusahaan wajib memiliki: pertama, komisaris independenyang jumlahnya secara proporsional sebanding dengan jumlah saham yang dimiliki oleh bukan pemegang saham pengendali dengan ketentuan jumlah komisaris independen sekurang-kurangnya 30 persen dari jumlah seluruh anggota komisaris; kedua, komite audit:untuk menilai pelaksanaan good corporate governance di perusahaan, adanya komite audit yang efektif merupakan salah satu aspek dalam kriteria penilaian; ketiga,dewan komisaris: prinsip-prinsip penting dalam dewan direksi yang menjadi acuan dalam usaha bisnis di Indonesia, terutama dalam hal komposisi dewan direksi yaitu komposisi direksi harus sedemikian rupa sehingga memungkinkan pengambilan putusan yang efektif, tepat dan cepat serta dapat bertindak secara independen; keempat,kepemilikan institusional: kemampuan manajer perusahaan untuk mengelola laba secara oportunistik dapat dibatasi oleh efektivitas pengawasan oleh para shareholder khususnya investor institusional; kelima, kepemilikan manajerial: pemusatan kepentingan dapat dicapai dengan memberikan kepemilikan saham kepada manajer. Jika manajer memiliki saham perusahaan, mereka akan memiliki kepentingan yang sama dengan pemilik sehingga dapat mengurangi konflik keagenan.

Masalah keagenan sering muncul karena adanya perbedaan kepentingan antara manajer dengan pemegang saham. Demsetz dan Lehn (1985) dalam Faisal (2004) menyimpulkan bahwa konsentrasi kepemilikan digunakan perusahaan untuk menghilangkan masalah keagenan. Adanya konsentrasi kepemilikan dari institusi dan dari pihak manajerial dianggap bisa mengurangi kecenderungan manajer dalam memanipulasi laba. Tindakan pengawasan perusahaan oleh pihak investor institusional dapat mendorong manajer untuk lebih memfokuskan perhatiannya terhadap kinerja perusahaan sehingga akan mengurangi perilaku oportunistikatau mementingkan diri sendiri. Kepemilikan institusional merupakan salah satu cara untuk memonitor kinerja manajer dalam mengelola perusahaan sehingga dengan adanya kepemilikan oleh institusi lain diharapkan bisa mengurangi perilaku manajemen laba yang dilakukan manajer. Midiastuty dan Mahfoedz (2003) menemukan bukti bahwa kepemilikan institusional berpengaruh negatif terhadap 
manajemen laba. Dari hasil penelitian tersebut, maka hipotesis penelitian dapat dinyatakan sebagai berikut.

$\mathbf{H}_{\mathbf{1}}$ : Kepemilikan institusional berpengaruh negatif terhadap manajemen laba.

Selain kepemilikan institusional, kepemilikan manajerial juga dianggap bisa mengurangi perilaku oportunistikmanajer. Kepemilikan manajerial dianggap sebagai salah satu faktor yang berpengaruh terhadap manajemen laba yang dilakukan manajer. Jika manajer mempunyai kepemilikan pada perusahaan maka manajer akan bertindak sesuai dengan kepentingan pemegang saham karena manajer juga mempunyai kepentingan di dalamnya. Faisal (2004) menyatakan bahwa besar kecilnya jumlah kepemilikan saham manajerial dalam perusahaan dapat mengindikasikan adanya keselarasan (congruance) kepentingan antara manajemen dengan pemegang saham. Dari penelitian tersebut, maka hipotesis penelitian ini dinyatakansebagai berikut.

$\mathbf{H}_{2}$ : Kepemilikan manajerial berpengaruh negatif terhadap manajemen laba.

Ukuran dewan komisaris memengaruhi praktik manajemen laba pada perusahaan. Nasution dan Setyawan (2007) menemukan pengaruh positif signifikan terhadap praktik manajemen laba pada perusahaan perbankan. Semakin besar ukuran dewan komisaris, maka semakin besar pula manajemen laba yang dilakukan perusahaan. Hal ini mengindikasi bahwa ukuran dewan komisaris yang besar tidak efektif dalam mengurangi praktik manajemen laba. Dari argumentasi dan riset terdahulu, maka hipotesis dalam penelitian ini dinyatakan sebagai berikut.

$\mathbf{H}_{3}$ : Ukuran dewan komisaris berpengaruh positif terhadap praktik manajemen laba.

Komisaris independen adalah anggota dewan komisaris yang tidak terafiliasi dengan direksi, anggota dewan komisaris lainnya dan pemegang saham pengendali, serta bebas dari hubungan bisnis atau hubungan lainnya yang dapat memengaruhi kemampuannya untuk bertindak independen atau bertindak semata-mata demi kepentingan perusahaan. Jumlah komisaris independen dalam satu perusahaan ditetapkan paling sedikit 30 persen dari jumlah seluruh komisaris.

Adanya dewan komisaris menjamin transparansi dan keinformatifan laporankeuangan sehingga memfasilitasi hak pemegang saham untuk mendapatkan informasi yang berkualitas. Hasil penelitian Nasution dan Setyawan (2007) menyatakan bahwa komposisi dewan komisaris independen berpengaruh negatif signifikan terhadap manajemen laba. Berdasarkan hasil penelitian tersebut, dapat disimpulkan bahwa komposisi dewan komisaris efektif dalam mengurangi manajemen laba perusahaan, sehingga hipotesis empat dinyatakansebagai berikut. 
$\mathbf{H}_{4}$ : Proporsi dewan komisaris independen berpengaruh negatif terhadap manajemen laba.

Komite audit adalah suatu komite yang dibentuk dewan komisaris untuk melakukan tugas pengawasan perusahaan. Komite audit mempunyai peran yang sangat penting dan strategis dalam hal memelihara kredibilitas proses penyusunan laporan keuangan seperti halnya menjaga terciptanya sistem pengawasan perusahaan yang memadai serta dilaksanakannya good corporate governance (Rachmawati dan Triatmoko 2007). Komite audit memiliki peranan yang penting dalam mengawasi berbagai aspek organisasi.Oleh karena itu, keberadaannya pun telah diatur oleh pemerintah dengan mewajibkan perusahaan mempunyai komite audit. Peran komite audit sangat diperlukan dalam hal pengawasan perusahaan. Tugas komite berhubungan dengan kualitas laporan keuangan, karena komite audit diharapkan dapat membantu dewan komisaris dalam pelaksanaan tugas yaitu mengawasi proses pelaporan keuangan oleh manajemen. Dengan adanya pengawasan dari komite audit, maka informasi yang disajikan dalam laporan keuangan lebih informatif dan berkualitas. Banyak penelitian yang mendukung keberadaan komite audit, di antaranya adalah hasil penelitian yang dilakukan Klein (2000) yang menunjukkan adanya hubungan negatif antara komite audit dengan manipulasi laba.

Hasil penelitian Nasution dan Setyawan (2007) menunjukkan pengaruh negatif signifikan antara komite audit dengan manajemen laba. Hal tersebut menunjukkan bahwa komite audit telah berhasil dalam mengurangi praktik manajemen laba perusahaan. Dengan argumentasi dan hasil penelitian terdahulu,maka hipotesis lima adalah sebagai berikut.

$\mathbf{H}_{5}$ : Komite audit berpengaruh negatif terhadap manajemen laba perusahaan.

Ukuran perusahaan dapat menentukan banyak sedikitnya praktik manajemen laba perusahaan. Perusahaan dengan ukuran yang relatif besar akan dilihat kinerjanya oleh publik sehingga perusahaan tersebut akan melaporkan kondisi keuangannya dengan lebih berhati-hati, lebih informatif dan lebih transparan. Oleh karena itu, perusahaan lebih sedikit dalam melakukan praktik manajemen laba. Sedangkan perusahaan yang mempunyai ukuran yang lebih kecil mempunyai kecenderungan untuk melakukan manajemen laba dengan melaporkan laba yang lebih besar untuk menunjukkan kinerja perusahaan yang memuaskan. Chtourou et al. (2001) menemukan bukti bahwa ukuran perusahaan berpengaruh negatif terhadap manajemen laba pada perusahaan di Amerika. Ini berarti, perusahaan yang besar mempunyai peluang yang lebih sedikit dalam melakukan praktik manajemen laba dan sebaliknya, perusahaan yang lebih kecil mempunyai peluang yang lebih besar dalam melakukan praktik manajemen laba. Berdasarkan hasil penelitian dan argumentasi di atas, maka hipotesis ke enam dinyatakan sebagai berikut. 
$\mathbf{H}_{6}$ : Ukuran perusahaan berpengaruh negatif terhadap manajemen laba.

Leverage merupakan rasio antara total kewajiban dengan total aset. Semakin besar rasio leverage, berarti semakin tinggi nilai utang perusahaan. Firth dan Smith (1992) dalam Saiful (2002) menjelaskan bahwa tingkat kewajiban yang tinggi menjadikan pihak manajemen perusahaan menjadi lebih sulit dalam membuat prediksi jalannya perusahaan ke depan. Semakin besar utang yang dimiliki perusahaan maka semakin ketat pengawasan yang dilakukan oleh kreditor, sehingga fleksibilitas manajemen untuk melakukan manajemen laba semakin berkurang. Hal ini mengindikasikan bahwa manajemen laba berkorelasi secara negatif dengan rasio utang terhadap total aset.

Penelitian yang dilakukan oleh Lobo dan Zhou (2001) dalam Veronica dan Bachtiar (2003) menemukan bahwa rasio utang berkorelasi secara negatif dengan manajemen laba. Berdasarkan uraian di atas maka rumusan hipotesis tujuh sebagai berikut.

$\mathbf{H}_{7}$ : Leverage berpengaruh negatif terhadap manajemen laba.

Manajemen laba dilakukan oleh manajer perusahaan pada faktor-faktor fundamental perusahaan, yaitu dengan intervensi pada penyusunan laporan keuangan berdasarkan akuntansi akrual. Padahal kinerja fundamental perusahaan tersebut digunakan oleh pemodal untuk menilai prospek perusahaan, yang tercermin pada kinerja saham. Haris (dalam Ujiyantho 2007) mengemukakan manajemen laba yang dilakukan manajer pada laporan keuangan tersebut akan memengaruhi kinerja keuangan saham. Pengaruh mekanisme corporate governance terhadap penurunan discretionaryaccruals sebagai ukuran dari manajemen laba dan berhubungan positif dengan Cash Flow Return On Asset (CFROA). Hasil ini diinterpretasikan sebagai indikasi bahwa CFROA merupakan fungsi positif dari indikator mekanisme corporate governance. Mekanisme corporate governance dapat mengurangi dorongan manajer melakukan earningsmanagement, sehingga CFROA yang dilaporkan merefleksikan keadaan yang sebenarnya. Berdasarkan uraian di atas hipotesis yang diajukan adalah.

$\mathbf{H}_{\mathbf{8}}$ : Manajemen laba berpengaruh positif terhadap kinerja keuangan.

\section{Model Penelitian}

Mekanisme Good Corporate Governance $(G C G)$ terdiri dari kepemilikan institusional, kepemilikan manajerial, ukuran dewan komisaris, proporsi komisaris independen dan ukuran komite audit disajikan dalam model penelitian (Gambar 1). 


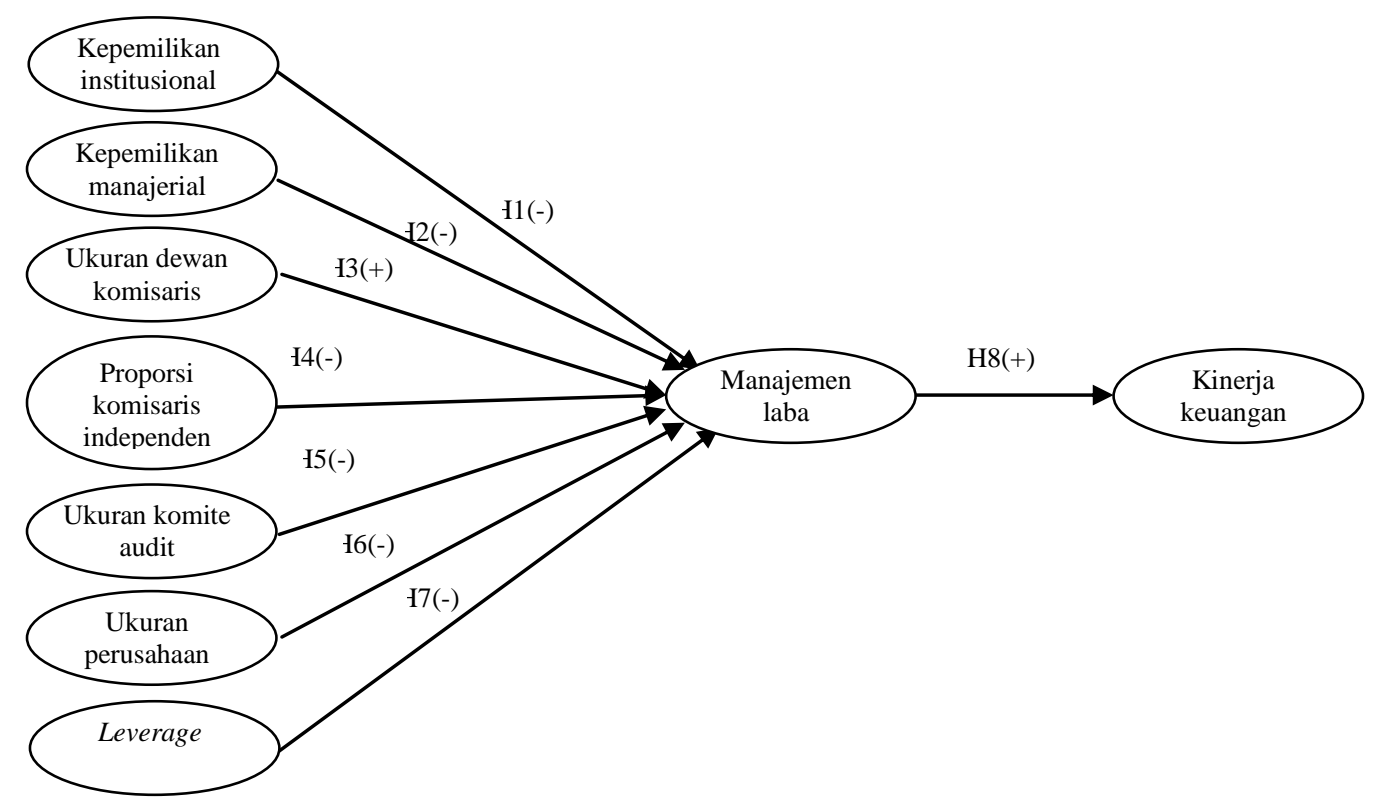

Gambar 1

Model Penelitian

\section{METODA PENELITIAN}

\section{Populasi dan Sampel}

Populasi yang digunakan dalam penelitian ini adalah semua perusahaan manufaktur yang terdaftar di Bursa Efek Indonesia (BEI). Periode pengamatan penelitian dilakukan dari tahun 2007-2009 agar lebih mencerminkan kondisi saat ini. Perusahaan yang menjadi sampel dalam penelitian ini adalah perusahaan manufaktur dan dipilih berdasarkan kriteria-kriteria tertentu (purposivesampling), yaitu: pertama, terdaftar di BEI pada tahun 2007-2009; kedua, perusahaan menerbitkan laporan keuangan dari tahun 2007-2009; ketiga, memiliki data mengenai kepemilikan institusional, kepemilikan manajerial, dewan komisaris independen, ukuran dewan komisaris dan komite audit.

\section{Jenis dan Sumber Data}

Data yang digunakan dalam penelitian ini berupa data sekunder yangdiambil dari laporan keuangan tahunan perusahaan dari tahun 2007-2009. Data sekunder yang dikumpulkan diperoleh dari Indonesian Capital Market Directory(ICMD) dan situs www.idx.co.id.

\section{Pengukuran Variabel Penelitian}

Variabel Dependen

Variabel dependen dalam penelitian ini, untuk model pertama adalahmanajemen laba, sedangkan untuk model kedua manajemen laba sebagai variabel independen dan kinerja keuangan sebagai variabel dependen.Dechow et al. 
(dalam Ujiyantho dan Pramuka 2007) menyebutkan bahwa penggunaan discretionary accruals sebagai proksi manajemen laba dihitung dengan menggunakan modified jones model karena model ini dianggap lebih baik di antara model lain untuk mengukur manajemen laba.Model tersebut dituliskan sebagai berikut:

Total accruals sesungguhnya :

$\mathrm{TAC}=$ NIit $-\mathrm{CFit}$

Keterangan:

NIit $=$ laba bersih (net income) perusahaan i pada periode $\mathrm{t}$

CFit $\quad=$ arus kas operasi (cash flow of operation) perusahaan i pada periode $\mathrm{t}$

Total accruals yang diestimasi dengan persamaan regresi OLS (Ordinary Least Square) adalah:

$\mathrm{TACt} / \mathrm{TA}_{\mathrm{t}-1}=(\beta) 1\left(1 / \mathrm{TA}_{\mathrm{t}-1}\right)+(\beta) 2\left(\Delta \mathrm{SALt}_{\mathrm{TA}} \mathrm{t-1}\right)+(\beta) 3\left(\mathrm{PPEt} / \mathrm{TA}_{\mathrm{t}-1}\right)+\mathrm{e}$.

Keterangan:

$\mathrm{TACt}=$ total accruals dalam periode $\mathrm{t}$

$\mathrm{TA}_{\mathrm{t}-1}=$ total asset periodE $\mathrm{t}-1$

$(\triangle) \mathrm{SAL} \quad=$ perubahan pendapatan atau penjualan bersih dalam periode $\mathrm{t}$

PPEt $\quad=$ property, plan, and equipment periode $\mathrm{t}$

$(\beta) 1,(\beta) 2,(\beta) 3=$ koefisien regresi

Dengan menggunakan koefisien regresi di atas nilai non discretionary accruals $(N D A)$ dapat dihitung dengan rumus:

$\mathrm{NDTACt}=(\beta) 1\left(1 / \mathrm{TA}_{\mathrm{t}-1}\right)+(\beta) 2\left[\left(\Delta \mathrm{SALt}_{-} \Delta \mathrm{RECt}\right) / \mathrm{TA}_{\mathrm{t}-1}\right]+(\beta) 3\left(\mathrm{PPEt} / \mathrm{TA}_{\mathrm{t}-1}\right)+\mathrm{e} \ldots(3)$

Keterangan:

$(\triangle) \mathrm{RECt} \quad=$ perubahan piutang usaha dalam periode $\mathrm{t}$

$(\beta) 1,(\beta) 2,(\beta) \quad$ = fitted coefficient yang diperoleh dari hasil regresi pada perhitungan total akrual

Diskresioner total akrual

DTACt $=$ TACt $/ \mathrm{TA}_{\mathrm{t}-1}-\mathrm{NDTACt}$

Keterangan:

DTACt $=$ diskresioner total akrual tahun $\mathrm{t}$

TACt $=$ total accruals tahun $\mathrm{t}$

NDTACt $=$ non akrual diskresioner pada tahun $\mathrm{t}$

Menurut Sulistyanto (2008), jika nilai DA nol maka menunjukkan perusahaan melakukan manajemen laba dengan pola perataan laba (income smoothing). Jika nilai DA positif maka menunjukkan bahwa manajemen laba dilakukan dengan pola 
penaikan laba (income increasing) dan nilai negatif menunjukkan manajemen laba dengan pola penurunan laba (income decreasing).

\section{Kinerja Keuangan}

Dalam penelitian ini kinerja keuangan diukur dengan menggunakan CFROAmenurut Ujiyantho dan Pramuka (2007). Arus kas menunjukkan hasil operasi yang dananya telah diterima tunai oleh perusahaan serta dibebani dengan beban yang bersifat tunai dan benar-benar sudah dikeluarkan oleh perusahaan, sehingga arus kas mempunyai nilai lebih untuk menjamin kinerja perusahan. CFROA dihitung dari laba sebelum bunga dan pajak ditambah depresiasi dibagi dengan total aset.

$$
\text { CFROA }=\frac{\text { EBIT }+ \text { Dep }}{\text { Asset }}
$$

Keterangan:

CFROA

EBIT

Dep

Asset

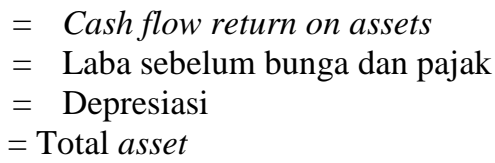

\section{Variabel Independen}

Kepemilikan institusional adalah jumlah persentase hak suara yang dimiliki oleh institusi. Kepemilikan institusional dalam penelitian ini menggunakan indikator persentase jumlah saham yang dimiliki institusi (perusahaan asuransi, bank, dana pensiun, dsb) dari seluruh modal saham yang beredar (Ujiyantho dan Pramuka 2007).

Boediono (2005) menyatakan kepemilikan manajerial adalah persentase suara yang berkaitan dengan saham dan option yang dimiliki oleh direksi dan manajer suatu perusahaan. Indikator yang digunakan adalah persentase jumlah saham yang dimiliki manajemen dari seluruh modal saham perusahaan.

Ujiyantho dan Pramuka (2007) mengemukakan bahwa variabel ukuran dewan komisaris diukur dengan jumlah total anggota dewan komisaris, baik yang berasal dari internal perusahaan maupun dari eksternal perusahaan sampel.

Proporsi dewan komisaris independen diukur dengan persentase jumlah dewan komisaris independen yang ada dalam perusahaan terhadap jumlah total komisaris yang ada dalam susunan dewan komisaris perusahaan sampel. Beasley (1996) dalam Nasution dan Setiawan (2007) menyatakan bahwa masuknya dewan komisaris yang berasal dari luar perusahaan meningkatkan efektivitas dewan tersebut dalam mengawasi manajemen untuk mencegah kecurangan laporan keuangan.

Komite audit adalah komite yang dibentuk oleh dewan komisaris untuk melakukan tugas pengawasan pengelolaan perusahaan. Indikator yang digunakan adalah jumlah komite audit yang terdapat pada perusahaan sampel.

Menurut Khomsiyah et al. (2004), ukuran perusahaan merupakan variabel yang diukur dari jumlah total aset perusahaan sampel yang ditransformasi dalam 
bentuk logaritma natural. Penggunaan nilai log total asset dimaksudkan untuk menghindari problem data natural yang tidak berdistribusi normal.

Leverage merupakan rasio antara total kewajiban dengan total asset. Semakin besar rasio leverage, berarti semakin tinggi nilai utang perusahaan. Leverage digunakan untuk menangkap insentif dalam tindakan manajemen laba ketika terjadi pelanggaran perjanjian hutang (Klein 2000). Rasio leverage dihitung dengan cara membagi antara total hutang dengan total aset.

Teknik dan Langkah-langkah Analisis

Terdapat dua model regresi dalam penelitian ini yaitu:

\section{Model 1}

$\mathrm{DTACt}=\alpha+\beta 1 \mathrm{KI}+\beta 2 \mathrm{KM}+\beta 3 \mathrm{UDK}+\beta 4 \mathrm{KDKI}+\beta 5 \mathrm{KA}+\beta 6 \mathrm{SIZE}+\beta 7 \mathrm{LEV}+\mathrm{e}$

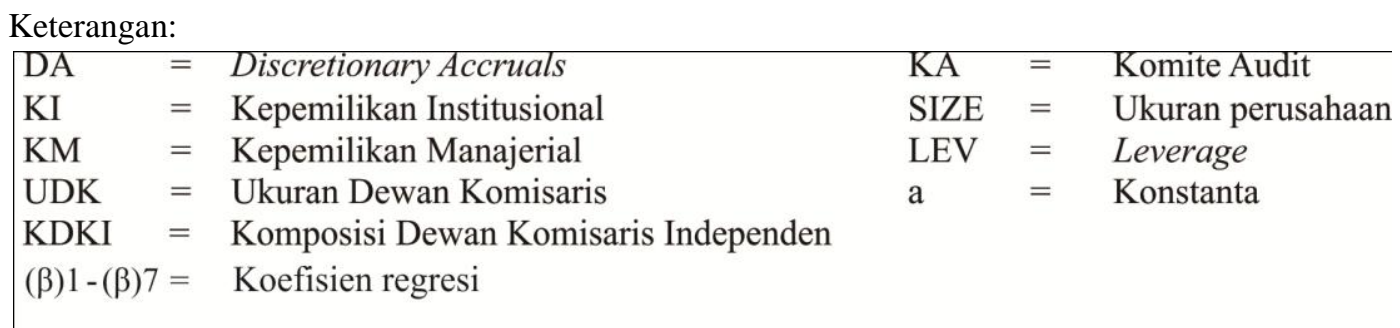

\section{Model 2}

Kinerja $=\alpha+\beta 8$ Manajemen Laba + e.

\section{ANALISIS DAN PEMBAHASAN}

\section{Gambaran Umum Objek Penelitian}

Penelitian ini menggunakan sampel perusahaan manufaktur yang terdaftar di BEI mulai tahun 2007-2009 yang diperoleh dari Indonesian Capital Market Directory (ICMD) dan www.idx.co.id. Jumlah perusahaan manufaktur yang terdaftar selama periode 2007-2009 sebanyak 157 perusahaan dan pemilihan sampel dilakukan dengan metoda purposive samplingdengan kriteria yang disajikanpada Tabel 1.

Tabel 1

Hasil Pemilihan Sampel

\begin{tabular}{clc}
\hline No & \multicolumn{1}{c}{ Keterangan } & Jumlah \\
\hline 1 & Perusahaan manufaktur yang terdaftar di BEI periode 2007 - 2009 & 157 \\
2 & Perusahaan manufaktur yang tidak memiliki kepemilikan saham manajerial & $(126)$ \\
& \& komite audit berturut - turut selama tahun 2007-2009 & \\
\hline
\end{tabular}


Dari keseluruhan jumlah perusahaan manufaktur yang ada di BEI periode 2007-2009, terdapat 31 perusahaan yang memenuhi kriteria yang telah ditetapkan dalam pemilihan sampel sehingga jumlah observasi (n) dalam penelitian ini adalah 3 $\mathrm{x} 31=93$.

\section{Statistik Deskriptif}

Langkah awal analisis dimulai dengan mengidentifikasi tendensi sebaran dari masing-masing variabel.Analisis statistik deskriptif digunakan untuk melihat kenderungan dari masing-masing variabel penelitian. Tabel 2 menyajikan ringkasan statistik deskriptif dari masing-masing variabel.

Tabel 2

Deskripsi Variabel Penelitian

\begin{tabular}{lcrrrr}
\hline Variabel Penelitian & N & Minimum & Maximum & Mean & $\begin{array}{c}\text { Std. } \\
\text { Dev }\end{array}$ \\
\hline KI & 93 & 0,322 & 0,964 & 0,682 & 0,160 \\
UDK & 93 & 2,000 & 10,00 & 3,828 & 1,685 \\
KM & 93 & 0,000 & 0,256 & 0,045 & 0,070 \\
Proporsi Komin & 93 & 0,200 & 0,800 & 0,377 & 0,116 \\
Uk. KomiteAudit & 93 & 3,000 & 4,000 & 3,215 & 0,413 \\
SIZE & 93 & 10,729 & 13,606 & 11,968 & 0,680 \\
LEV & 93 & 0,005 & 2,485 & 0,458 & 0,415 \\
ML & 93 & $-0,376$ & 1,285 & 0,000 & 0,212 \\
KINERJA & 93 & $-0,223$ & 1,485 & 0,112 & 0,171 \\
\hline Sub
\end{tabular}

Sumber: Data sekunder yang diolah

Deskripsi mengenai kepemilikan saham oleh institusi (KI) menunjukkan ratarata sebesar 68,19 persen. Hal ini berarti bahwa rata-rata saham dari perusahaan sampel selama tahun 2007-2009 diperoleh bahwa 68,19 persen sahamnya dimiliki oleh institusi atau organisasi lain (perusahaan atau institusi lain). Nilai terendah dari kepemilikan saham institusi adalah sebesar 0,3220 yang dimiliki oleh PT Lion Mesh Prima Tbk dan nilai tertinggi adalah 0,9643 yang dimiliki oleh PT Tira AusteniteTbk. Tingginya kepemilikan saham institusi dapat berfungsi sebagai pengontrol manajemen.

Deskripsi mengenai anggota dewan komisaris (UDK) secara rata-rata diperoleh sebesar 3,828. Hal ini ini berarti bahwa secara umum perusahaan sampel memiliki anggota dewan komisaris yang berjumlah empat orang. Jumlah dewan 
komisaris yang paling sedikit adalah sebanyak dua orang dan jumlah terbanyak adalah sebanyak sepuluh orang yaitu pada PT Indofood Sukses Makmur Tbk.

Deskripsi kepemilikan saham oleh manajerial (KM) menunjukkan rata-rata sebesar 4,45 persen. Hal ini berarti bahwa rata-rata saham dari perusahaan sampel selama tahun 2007-2009, diperoleh bahwa 4,45 persen sahamnya dimiliki oleh manajerial (anggota dewan komisaris maupun dewan direksi). Jumlah kepemilikan saham manajerial yang paling rendah adalah sebesar 0,01 persen yang dimiliki oleh PT Hexindo Adiperkasa Tbk dan PT Langgeng Makmur Plastik IndustriTbk dan nilai tertinggi adalah 25,61 persen yang dimiliki oleh PT Lion Mesh Prima Tbk. Kepemilikan saham oleh manajerial menunjukkan kepentingan ganda dari manajer yaitu sebagai agent sekaligus sebagai principal. Dalam hal ini diharapkan manajer yang memiliki saham dapat mewakili kepentingan pemegang saham lainnya.

Deskripsi dewan komisaris independen (KOMINDP) dari perusahaan sampel diperoleh sebesar 37,67 persen. Hal ini ini berarti bahwa jumlah komisaris independen dari perusahaan sampel rata-rata sebesar 37,67 persen dari seluruh jumlah dewan komisaris. Kondisi demikian menunjukkan bahwa secara rata-rata perusahaan-perusahaan sampel telah memenuhi syarat minimal 30 persen anggota dewan komisaris independen. Jumlah terendah adalah sebesar 20,00 persen yang ada di PT Alumindo Light Metal Industry Tbk tahun 2007-2009 dan PT Lautan Luas Tbk tahun 2007 sedangkan jumlah tertinggi mendapai 80 persen yang ada di PT Gudang Garam Tbk tahun 2009.

Jumlah komite audit (KOMAUD) yang diukur berdasarkan jumlah komite audit sebagai auditor internal perusahaan secara rata-rata diperoleh sebesar 3,2151. Hal ini ini berarti bahwa secara umum perusahaan sampel memiliki anggota komite audit yang berjumlah tiga orang. Jumlah komite audit yang paling sedikit adalah sebanyak tiga orang dan jumlah terbanyak adalah sebanyak empat orang.

Ukuran perusahaan yang diukur dengan menggunakan logaritma total aset menunjukkan rata-rata sebesar 11,9680. Nilai logaritma total aset terendah adalah sebesar 10,7297 yaitu PT Perdana Bangun Pusaka Tbk pada tahun 2008 dan nilai logaritma total aset terbesar adalah 13,6062 yaitu PT Indofood Sukses Makmur Tbk tahun 2009. Perusahaan besar banyak menjadi perhatian banyak pihak.

Ukuran rasio leverage yang diukur dengan menggunakan total hutang dibagi total aset menunjukkan rata-rata sebesar 0,4581. Nilai rasio leverage rata-rata tersebut lebih kecil dari 0,50 yang berarti bahwa perusahaan sampel lebih banyak menggunakan modal sendiri sebagai sumber pendanaan perusahaan. Leverage terendah adalah sebesar 0,0051 yang ada pada PT Mandom IndonesiaTbk tahun 2007 dan leverage tertinggi adalah 2,4854 yang ada pada PT Jakarta Kyoei Steel Works Tbk tahun 2009.

Estimasi rata-rata Manajemen Laba (ML) yang diukur dengan Discretionary Acrual(DA) dengan estimasi model modified jones diperoleh rata-rata $D A$ sebesar 0,0000. Hal ini karena estimasi model dengan model regresi akan memberikan nilai residual sebesar nol. Manajemen laba dalam hal ini dilakukan dengan cara 
menaikkan laba maupun menurunkan laba. Nilai minimum DA adalah sebesar 0,3759 yang menunjukkan kecilnya tindakan menurunkan laba, sedangkan nilai $D A$ tertinggi adalah sebesar 1,2850 yang menunjukkan adanya manajemen laba dari selisih aktualestimasi akrual yang seharusnya diperoleh perusahaan.

Deskripsi variabel kinerja perusahaan dalam penelitian ini diukur dengan menggunakan CFROA menunjukkan rata-rata sebesar 0,1117. Rata-rata tersebut menunjukkan bahwa secara rata-rata perusahaan sampel telah memiliki laba sebelum pajak yang telah dikurangi dengan depresiasi hingga 11,17 persen dari total aset perusahaan. Nilai CFROA terendah adalah sebesar -0,2229 dan nilai CFROA tertinggi adalah sebesar 1,4850.

\section{Pengujian Hipotesis}

\section{Pengaruh Mekanisme Corporate Governance, Ukuran Perusahaan dan Leverage terhadap Manajemen Laba}

Tabel 3 menunjukkan nilai adjusted $R^{2}$ adalah 0,253. Hal ini berarti kemampuan variabel independen yaitu komite audit, kepemilikan saham manajerial, kepemilikan saham institusi, komisaris independen, jumlah dewan komisaris, ukuran perusahaan dan leveragedalam menerangkan manajemen laba adalah 25,3 persen. Sisanya yaitu 74,7 persen dijelaskan oleh faktor-faktor lain selain variabel independen tersebut.

Tabel 3

Regresi Mekanisme Corporate Governance, Ukuran perusahaandan Leverageterhadap Manajemen Laba

\begin{tabular}{lccc}
\hline \multicolumn{1}{c}{ Variabel Penelitian } & Koefisien Regresi & T & Sig. \\
\hline Konstanta & 0,028 & 0,088 & 0,930 \\
KI & $-0,250$ & $-2,689$ & 0,009 \\
KM & 0,012 & 0,050 & 0,961 \\
UDK & $-0,016$ & $-1,782$ & 0,079 \\
Proporsi_Komin & 0,073 & 0,746 & 0,458 \\
Uk_KomiteAudit & 0,034 & 1,217 & 0,227 \\
SIZE & 0,007 & 0,270 & 0,788 \\
LEV & $-0,102$ & $-3,898$ & 0,000 \\
\hline $\mathbf{R}^{2}=\mathbf{0 , 3 1 4} \quad$ Adjusted $\mathbf{R}^{\mathbf{2}=\mathbf{0 , 2 5 3}} \mathbf{F = \mathbf { 5 , 1 0 2 }}$ & Sig.F= 0,000 & \\
\hline Sumber: data diolah 2011 & & &
\end{tabular}

\section{Pengaruh Manajemen Laba terhadap Kinerja Keuangan.}

Hasil pengujian hipotesis delapan dapat dilihat padaTabel 4.

Tabel 4

Regresi Manajemen Laba terhadap CFROA

\begin{tabular}{lrrr}
\hline \multicolumn{1}{c}{ Variabel Penelitian } & Koefisien Regresi & t & Sig. \\
\hline Konstanta & 0,103 & 10,402 & 0,000 \\
ML & 0,142 & 1,672 & 0,098 \\
\hline
\end{tabular}

Sumber: data diolah 2011 


\section{PEMBAHASAN}

Berdasarkan hasil regresi diketahui bahwa jumlah kepemilikan saham oleh institusional menunjukkan berpengaruh negatif signifikan terhadap manajemen laba. Hasil penelitian ini sejalan dengan penelitian Midiastuti dan Machfoedz (2003) yang menyatakan bahwa kepemilikan institusional berpengaruh negatif signifikan terhadap manajemen laba sehingga pengawasan yang cukup ketat dapat memperkecil peluang terjadinya tindakan manajemen laba yang dilakukan oleh manajer yang dapat merugikan investor.

Berdasarkan hasil pengujian, variabel kepemilikan manajerial tidak berpengaruh secara signifikan terhadap manajemen laba. Hasil ini menjelaskan bahwa kepemilikan saham oleh manajerial memiliki keuntungan dan kerugian bagi perusahaan secara umum. kepemilikan saham cenderung mengurangi informasi yang asimetri kepada para pemegang saham. Hasil ini bertentangan dengan penelitian Ujiyantho dan Pramuka (2007), serta Faisal (2004) yang menemukan adanya pengaruh negatif signifikan. Dari sudut pandang teori akuntansi, manajemen laba sangat ditentukan oleh motivasi manajer perusahaan. Motivasi yang berbeda akan menghasilkan besaran manajemen laba yang berbeda.

Variabel ukuran dewan komisaris berpengaruh negatif tidak signifikan terhadap variabel discretionary accruals. Hasil penelitian ini bertentangan dengan penelitian yang dilakukan Midiastuty dan Machfoedz (2003), serta Nasution dan Setyawan(2007). Boediono (2005) menyebutkan bahwa besar kecilnya dewan komisaris bukanlah menjadi penentu dari efektivitas pengawasan terhadap manajemen perusahaan. Namun, efektivitas pengawasan tergantung bagaimana komunikasi,koordinasi dan pembuatan keputusan.

Penempatan atau penambahan anggota dewan komisaris independen dimungkinkan hanya sekedar memenuhi ketentuan formal, sementara pemegang saham mayoritas (pengendali/founders) masih memegang perananpenting sehingga kinerja dewan tidak meningkat bahkan turun (Boediono 2005). Siregar dan Utama (2005) juga menyatakan bahwa pengangkatan dewan komisaris independen oleh perusahaan mungkin hanya dilakukan untuk pemenuhan regulasi saja tapi tidak dimaksudkan untuk menegakkan Good Corporate Governance (GCG) di dalam perusahaan. Kondisi ini juga ditegaskan dari hasil survey Asian Development Bank (dalam Boediono 2005) yang menyatakan bahwa kuatnya kendali pendiri perusahaan dan kepemilikan saham mayoritas menjadikan dewan komisaris tidak independen dan fungsi pengawasan yang seharusnya menjadi tanggung jawabnya menjadi tidak efektif. Sulistyanto (2008) menyebutkan bahwa kondisi di pasar modal Indonesia merupakan emerging market dengan ciri utama kepemilikan yang terkonsentrasi pada kelompok tertentu (closely held). Akibatnya, pemegang saham mayoritas mempunyai akses yang besar untuk mempengaruhi keputusan manajerial yang sering merugikan dan melanggar asas akuntabilitas dan keadilan pemegang saham minoritas. 
Penelitian Siregar dan Utama (2005) menemukan bukti bahwa keberadaan komite audit tidak terbukti memengaruhi besaran pengelolaan laba secara signifikan. Hal ini mungkin terjadi karena pengangkatan komite audit oleh perusahaan hanya dilakukan untuk pemenuhan regulasi saja tetapi tidak dimaksudkan untuk menegakkan $G C G$ di perusahaan.

Ukuran perusahaan tidak berpengaruh secara signifikan terhadap manajemen laba. Hal tersebut berarti belum tentu perusahaan-perusahaan kecil cenderung melakukan manajemen laba dibandingkan perusahaan besar. Perusahaan kecil mungkin lebih memiliki kesempatan tumbuh yang lebih baik sehingga akan membutuhkan dana eksternal yang lebih besar. Besarnya kebutuhan atas dana eksternal akan meningkatkan kebutuhan atas mekanisme corporate governance yang baik.

Leverage menunjukkan pengaruh negatif signifikan terhadap manajemen laba. Hasil memperjelas bahwa dalam hal ini nampaknya jika tingkat kewajiban tinggi akan menjadikan pihak manajemen perusahaan menjadi lebih sulit dalam membuat prediksi jalannya perusahaan ke depan. Semakin besar utang yang dimiliki perusahaan maka semakin ketat pengawasan yang dilakukan oleh kreditor, sehingga fleksibilitas manajemen untuk melakukan manajemen laba semakin berkurang. Penelitian ini sejalan dengan penelitian Rachmawati dan Triatmoko (2007), Veronika (2003) juga penelitian Firth dan Smith (1992) dalam Saiful (2002) yang menjelaskan bahwa tingkat kewajiban yang tinggi menjadikan pihak manajemen perusahaan menjadi lebih sulit dalam membuat prediksi jalannya perusahaan ke depan. Semakin besar utang yang dimiliki perusahaan maka semakin ketat pengawasan yang dilakukan oleh kreditor, sehingga fleksibilitas manajemen untuk melakukan manajemen laba semakin berkurang.

Hasil penelitian mendapatkan bahwa ukuran manajemen laba berpengaruh positif signifikan terhadap CFROA yang merupakan ukuran kinerja perusahaan. Hal ini menunjukkan bahwa keberadaan manajemen laba berpengaruh pada kinerja keuangan perusahaan. Hasil penelitian ini mendukung temuan empirisHaris (dalam Ujiyantho dan Pramuka 2007) dan Boediono (2005). Dalam riset tersebut dijelaskan bahwa pemakai laporan keuangan beranggapan CFROA yang dilaporkan dapat menunjukkan kinerja manajemen. Tujuan manajemen laba adalah mengatur laporan keuangan agarsesuai dengan apa yang diinginkan oleh manajer terkait dengan kepentingannya.Dengan demikian, semakin tinggi manajemen laba yang dilakukan maka kinerja keuangan akan semakin terlihat baik, dalam kaitannya dengan tujuan melakukan manajemen laba adalah untuk memperbaiki laporan keuangan perusahaan yangberbeda dengan kondisi yang sebenarnya.

\section{SIMPULAN DAN REKOMENDASI}

\section{Simpulan}


Kepemilikan saham institusional dan leverage memiliki pengaruh negatif signifikan terhadap manajemen laba dan manajemen laba memiliki pengaruh positif signifikan terhadap kinerja keuangan perusahaan. Sedangkan variabel kepemilikan manajerial, ukuran dewan komisaris, proporsi dewan komisaris independen, ukuran komite audit dan ukuran perusahaan tidak berpengaruh signifikan terhadap manajemen laba.

\section{Implikasi}

1. Bagi perusahaan

Perusahaan sebaiknya lebih melibatkan kepemilikan institusional dan meningkatkan pendanaan melalui utang, untuk mengurangi manajemen laba dalam perusahaan.

2. Bagi investor

Manajemen laba adalah tindakan yang tidak dapat dihindarkan karena laba disusun berdasarkan norma atau standar akuntansi keuangan. Para investor sebaiknya berhati-hati dalam pengambilan keputusan bisnis, tidak hanya terfokus pada informasi laba, tetapi juga mempertimbangkan informasi non keuangan, seperti keberadaan mekanisme internal perusahaan. Misalnya, dengan memilih perusahaan yang memiliki kepemilikan institusional dan nilai hutang yang cukup besar karena fleksibilitas manajemen untuk melakukan manajemen laba akan berkurang. Selain itu investor juga bisa mempertimbangkan untuk memilih perusahaan yang melakukan manajemen laba karena kinerja keuangan akan meningkat, karena manajemen laba merupakan pilihan kebijakan akuntansi oleh manajer, walaupun tindakan manajer tersebut untuk meningkatkan (mengurangi) laba yang dilaporkan saat ini atas suatu unit usaha dimana manajer bertanggung jawab, namun tidak mengakibatkan peningkatan (penurunan) profitabilitas ekonomi jangka panjang unit tersebut.

\section{SARAN UNTUK PENELITIAN MENDATANG}

Penelitian selanjutnya dapat juga melakukan penelitian yang khusus ditujukan untuk mengembangkan model pengukuran pengelolaan laba yang lebih akurat, misal per industri. Sehingga karakteristik industri yang berbeda yang dapat memengaruhi pengelolaan laba dapat dimasukkan ke dalam model pengukuran tersebut.Dengan mengembangkan model per industri ini juga dapat mengidentifikasi perbedaan pola pengelolaan laba di tiap industri. Selain itu untuk pengukuran komite audit, dapat menggunakan aktivitas komite audit, tingkat kehadiran atau latar belakang pendidikan. 


\section{DAFTAR PUSTAKA}

Anthony, R. N., dan V. Govindarajan. 2005. Sistem Pengendalian Manajemen. Jakarta: Salemba Empat.

Bangun dan Vincent. 2008. Analisis hubungan komponen $G C G$ terhadap manajemen laba dengan kinerja keuangan pada perusahaan manufaktur yang terdaftar di BEI. Jurnal AkuntansiTahun XII.No.03.

Belkaoui dan A. Riahi. 2004. Accounting Theory. Edisi Kelima. Jakarta: Salemba Empat.

Boediono, S. B.,dan Gideon. 2005. Kualitas laba: Studi pengaruh mekanisme corporate governancedan dampak manajemen laba dengan menggunakan analisis jalur. Simposium Nasional Akuntansi VIII Solo.

Budi S.P., dan P. Pratiwi. 2009. Pengaruh earning power terhadap praktek manajemen laba.Jurnal Media Ekonomi.Vol.14.No.1.

Chtourou, S. M., J. Bedard, dan L. Courteau. 2001. Corporate governance and earnings management. Available at: www.ssrn.com.

Faisal. 2004. Analisis agency cost, struktur kepemilikan dan mekanisme corporate governance. Simposium Nasional Akuntansi VII Denpasar.

Ghozali, I. 2006. Aplikasi Analisis Multivariate dengan Program SPSS. Edisi Keempat. Semarang: Badan Penerbit Universitas Diponegoro.

Hapsoro, D. 2008. Pengaruh mekanisme corporate governanceterhadap kinerja perusahaan: Studi empiris di pasar modal Indonesia. Jurnal Akuntansi \& Manajemen.Vol.19 No.3.

Herawati, N., dan Z. Baridwan. 2007. Manajemen laba pada perusahaan yang melanggar perjanjian hutang. Simposium Nasional Akuntansi 10Makassar.

Jensen, M. C.,dan W. H. Meckling. 1976. Theory of the firm: managerial behavior, agency costs and ownership structure. Journal of Financial Economics. Vol.3. No.4: 305-360.

Khomsiyah, D., dan R.G. Rika. 2004. Hubungan corporate governancedan kinerja perusahaan. Simposium Nasional Akuntansi VII Denpasar.

Kieso, E. D., J. J. Weygandt,dan T. D. Warfield. 2002. Intermediate Accounting.Edisi Kesepuluh, Jilid 1. Jakarta: Erlangga.

Klein, A. 2000. Audit committee, boards of director characteristics, and earnings management. Available at: www.ssrn.com.

Komite Nasional Corporate Governance. 2002. Pedoman pembentukan komite audit yang efektif. Available at: www.governance-indonesia.com.

Midiastuty, P. P., dan M. Machfoedz. 2003. Analisis hubungan mekanisme corporate governancedan indikasi manajemen laba. Simposium Nasional Akuntansi VI Surabaya.

Nasution, M., dan Setyawan. 2007. Pengaruh corporate governanceterhadap manajemen laba di industri perbankan Indonesia. Simposium Nasional Akuntansi X Makassar. 
Rahmawati, A., dan H. Triatmoko. 2007. Analisis faktor-faktor yang memengaruhikualitas laba dan nilai perusahaan. Simposium Nasional Akuntansi X Makassar.

Saiful. 2002. Hubungan manajemen laba (earning management) dengan kinerja operasi dan returnsaham disekitar IPO.Simposium Nasional Akuntansi $V$,Semarang.

Scott, W. R. 2000. Financial Accounting Theory. USA:Prentice-Hall.

Siallagan, H., dan M. Machfoedz. 2006. Mekanisme corporate governance, kualitas laba dan nilai perusahaan. Simposium Nasional Akuntansi IX Padang.

Siregar, S. V., dan S. Utama. 2005. Pengaruh struktur kepemilikan, ukuran perusahaan, dan praktek corporate governanceterhadap pengelolaan laba (earnings management). Simposium Nasional Akuntansi VIII Solo.

Sulistyanto, S. 2008. Manajemen Laba Teori dan Model Empiris. Jakarta: Gramedia Widiasarana.

Tarjo. 2008. Pengaruh konsentrasi kepemilikan institusional dan leverageterhadap manajemen laba, nilai pemegang saham serta cost of equitycapital. Simposium Nasional Akuntansi XIPontianak.

Ujiyantho. M. A., dan A. Pramuka. 2007. Mekanisme corporate governance, manajemen laba dan kinerja perusahaan. Simposium Nasional Akuntansi X Makasar.

Veronica, S., dan Y. Bachtiar. 2003. Hubungan antara manajemen laba dengan tingkat pengungkapan laporan keuangan. Simposium Nasional Akuntansi VI, Surabaya. 
